\title{
Soil moisture study under drip irrigated cabbage (Brassica oleracea L. var. capitata) in sandy loam soil
}

DALESHWAR RAJAK AND PRAVIN DAHIPHALE

Received : 23.06.2017; Revised : 18.08.2017; Accepted : 03.09.2017

See end of the Paper for authors' affiliation

Correspondence to :

DALESHWAR RAJAK

Zonal Research Station

(BAU), Darisai, East

Singhbhum (JHARKHAND)

INDIA

Email : drajak76@rediffmail.

com
-ABSTRACT : Field experiment was conducted at Plasticulture Farm, CTAE, Udaipur, Rajasthan during Rabi season of 2012-2013 and 2013-2014 on sandy loam soil to study the moisture distribution pattern of sandy loam soil under the drip irrigated cabbage at various irrigation and fertigation levels. The experiments were laid out in Factorial Randomized Block Design with ten treatments which included three irrigation levels 100, 80 and $60 \%$ of evapotranspiration (ET) along with three fertigation levels, viz., 100, 75 and 50\% of recommended dose of fertilizer and one control (Surface irrigation at $1.0 \mathrm{IW} / \mathrm{CPE}$ ratio $+100 \% \mathrm{RDF}$ through farmer's practice) and were replicated thrice. Observations revealed that highest yield $\left(340.73 \mathrm{q} \mathrm{ha}^{-1}\right)$ was recorded with the treatment combination of drip irrigation with $80 \%$ ET and fertigation @ $75 \%$ RDF. The crops treated with 80 per cent ET experienced that the moisture content was maintained near to field capacity at the root zone of the crop. The vertical and radial spread of water in the soil increased with the amount of irrigation. In all the treatments, the soil moisture distribution along the vertical direction increased and laterally it was decreased.

- KEY WORDS : Drip irrigation, Fertigation, Soil moisture distribution, Cabbage

- HOW TO CITE THIS PAPER : Rajak, Daleshwar and Dahiphale, Pravin (2017). Soil moisture study under drip irrigated cabbage (Brassica oleracea L. var. capitata) in sandy loam soil. Internat. J. Agric. Engg., 10(2) : 468-473, DOI: 10.15740/HAS/IJAE/10.2/468-473. 